\title{
Attenuation Coefficient and Propagation Speed Estimates of Intercostal Tissue as a Function of Pig Age
}

\author{
Rita J. Miller, Leon A. Frizzell, Senior Member, IEEE, James F. Zachary, \\ and William D. O'Brien, Jr., Fellow, IEEE
}

\begin{abstract}
Attention coefficient and propagation speed of intercostal tissues were estimated from chest walls removed postmortem (pm) from 15 5.3 \pm 2.3 -day-old, $1931 \pm 6$ day-old, and 15 61 \pm 3 -day-old crossbred pigs. These ultrasonic propagation properties were determined from measurements through the intercostal tissues, from the surface of the skin to the parietal pleura. The chest walls were placed in a $0.9 \%$ sodium chloride solution, sealed in freezer bags, and stored at $-15^{\circ} \mathrm{C}$ prior to measurements. When evaluated, chest-wall storage time ranged between 1 and 477 days $\mathrm{pm}$. All chest walls were allowed to equilibrate to $22^{\circ} \mathrm{C}$ in a water bath prior to evaluation. There was an age dependency of the intercostal tissue propagation speed, with the speed increasing with increasing age. The attenuation coefficient of intercostal tissue was shown to be independent of the age of the pig at the discrete frequencies of 3.1 and 6.2 MHz. For pig intercostal tissues, the estimated attenuation coefficient over the 3.1-9.2 MHz frequency range was $A=1.94 f^{0.90}$ where $A$ is in decibels per centimeter $(\mathrm{dB} / \mathrm{cm})$ and $\mathrm{f}$ is the ultrasonic frequency in megahertz. In order to determine if there was an effect of storage time pm on estimates of attenuation coefficient, a second experiment was conducted. Five of the youngest pig chest walls measured on day $1 \mathrm{pm}$ in the first experiment were stored at $4^{\circ} \mathrm{C}$ prior to the first evaluation then stored at $-15^{\circ} \mathrm{C}$ before being measured again at 108 days pm. There was no difference in the estimated intercostal tissue attenuation coefficient as a function of storage time pm.
\end{abstract}

\section{INTRODUCTION}

$\mathrm{T}$ HE purpose of this study was to determine the attenuation coefficient of intercostal tissue in the 3 to $9 \mathrm{MHz}$ frequency range as a basis to provide an estimate of the exposure (acoustic pressure, for example) at the lung surface. This frequency range is common in clinical ultrasound and is the frequency range used to study the interaction between ultrasound and lung tissue. The ultrasound fields are calibrated in water, and in order to provide an in situ (at the pleural) surface exposure estimate, the ultrasonic insertion loss between the skin sur-

Manuscript received August 27, 2001; accepted May 15, 2002. This work was supported by NIH Grant HL58218 awarded to W.D.O. and J.F.Z.

R. J. Miller, L. A. Frizzell, and W. D. O'Brien, Jr., are with the Bioacoustics Research Laboratory, Department of Electrical and Computer Engineering, University of Illinois at Urbana-Champaign, Urbana, IL 61801 (e-mail: wdo@uiuc.edu).

L. A. Frizzell, J. F. Zachary, and W. D. O'Brien, Jr. are with the Bioengineering Program, University of Illinois at UrbanaChampaign, Urbana, IL 61801. face and the lung surface must be known. A number of research groups have reported experimental findings documenting lung hemorrhage in mice [1]-[12], rats [11]-[18], rabbits [6], [8], monkeys [19], and pigs [8], [19]-[22] at levels of ultrasound exposure and pulsing conditions consistent with those used for ultrasonography in humans. Some of these reports did not estimate the exposure at the lung surface, but rather reported exposure values at the skin surface. Some of them used published attenuation coefficient values and others used measured values to provide in situ exposure estimates. Our approach has been to measure the attenuation coefficient of the intercostal tissue from a selected number of animals that were included in our ultrasound-induced lung hemorrhage studies. This approach provides a more meaningful estimate of the in situ exposure.

We know of only two published reports of measurements of the attenuation coefficient of intercostal tissue of pigs [20], [21]. These two reports, by the same research group, used their measured values to estimate the in situ exposures. However, these reports were of pigs in age ranges between 0 and 10 days. In our age-dependent, ultrasoundinduced lung hemorrhage study of pigs [22], three pig-age ranges were used (2-10 days, 30-51 days, 46-71 days). Thus, in order to estimate the in situ exposure levels, it was necessary to measure the intercostal tissue attenuation coefficient of pigs within these approximate age ranges in order to determine whether there was an age-dependent effect.

\section{Materials and Methods}

Two separate experiments are reported. Experiment 1 estimated the intercostal tissue attenuation coefficient and propagation speed for randomly selected pigs as a function of age (and chest-wall thickness) that were included in an ultrasound-induced lung hemorrhage study [22]. Experiment 2 estimated the intercostal tissue attenuation coefficient and propagation speed as a function of sample storage time. The experimental protocol was approved by the Laboratory Animal Care Advisory Committee at the University of Illinois at Urbana-Champaign and satisfied all campus and National Institutes of Health (NIH) rules for the humane use of laboratory animals. The nursing (youngest age group) crossbred pigs were housed in an As- 


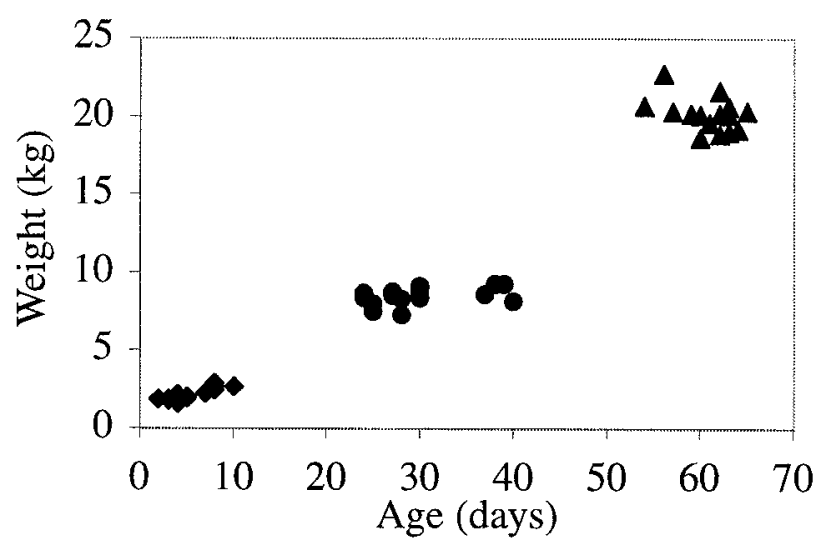

Fig. 1. Weight as a function of age for the 49 crossbred pigs whose intercostal tissue was evaluated.

sociation for Assessment and Accreditation of Laboratory Animal Care, Rockville, MD (AAALAC)-approved animal facility, with the sows in farrowing crates. The other crossbred pigs were reared and housed in an AAALACapproved animal facility. The AAALAC is a private, nonprofit organization that promotes the humane treatment of animals in science through a voluntary accreditation program.

\section{A. Experiment 1}

Fifteen 5.3 \pm 2.3 -day-old neonate crossbred pigs (weight: $2.2 \pm 0.4 \mathrm{~kg}$ ), $1931 \pm 6$-day-old crossbred pigs (weight: $8.5 \pm 0.5 \mathrm{~kg}$ ), and $1561 \pm 3$-day-old crossbred pigs (weight: $20 \pm 1.1 \mathrm{~kg}$ ) were used in this study (Fig. 1). The mean \pm standard deviation intercostal tissue thicknesses were, respectively, $1.12 \pm 0.30 \mathrm{~cm}, 2.13 \pm 0.59 \mathrm{~cm}$, and $2.30 \pm 0.42 \mathrm{~cm}$. The source of the pigs was the University of Illinois Veterinary Research Farm (Urbana, IL); the chest walls were obtained at random from an ongoing ultrasound-induced lung hemorrhage study [22]. These three age groups will be referred to as 5-day, 31-day, and 61-day pigs for convenience.

The pigs were anesthetized with an intramuscular injection of ketamine hydrochloride $(2.2 \mathrm{mg} / \mathrm{kg})$, xylazine $(2.2 \mathrm{mg} / \mathrm{kg})$, and tiletamine/zolazepam $(4.4 \mathrm{mg} / \mathrm{kg})$. The thorax was shaved with an electric clipper, followed by a depilatory agent (Nair ${ }^{\circledR}$ Carter-Wallace, Inc., New York, NY). Following the ultrasound-induced lung hemorrhage exposure procedure [22], pigs were euthanized under anesthesia with an intravenous injection of sodium pentobarbital $(0.22 \mathrm{~mL} / \mathrm{kg})$. Chest walls were removed as previously described [23], placed in a $0.9 \%$ sodium chloride solution, sealed in Glad-Lock ${ }^{\circledR}$ Zipper $^{\text {TM }}$ (The Glad Products Co., Oakland, CA) freezer bags, and stored at $-15^{\circ} \mathrm{C}$. The 5 day-pig chest walls were stored between 1 and 174 days, 31day-pig chest walls were stored between 42 and 477 days, and 61-day-pig chest walls were stored between 47 and 470 days prior to determining attenuation coefficient and propagation speed estimates.

\section{B. Experiment 2}

Chest walls from five 5.6 \pm 2.3 -day-old neonate crossbred pigs (weight: $2.4 \pm 0.4 \mathrm{~kg}$ ) were evaluated at 108-days $\mathrm{pm}$ to assess whether storage time affected attenuation coefficient and propagation speed estimates. These five chest walls were obtained from the group of 15,5 -day-old pigs in Experiment 1. The same five pig chest walls were evaluated at 1- and 108-days $\mathrm{pm}$. The chest walls were placed in a $0.9 \%$ sodium chloride solution, sealed in Glad-Lock ${ }^{\circledR}$ Zipper ${ }^{\mathrm{TM}}$ freezer bags, and stored at $4^{\circ} \mathrm{C}$ prior to being evaluated at day $1 \mathrm{pm}$ then stored at $-15^{\circ} \mathrm{C}$ before being evaluated again at day $108 \mathrm{pm}$.

\section{Measurement and Analysis Techniques}

Experimental procedures as described previously [23], [24] using a standard through-transmission insertion-loss technique [25] were used to estimate the attenuation coefficient of the chest-wall intercostal space. The propagation speed was estimated from the transit time difference via a standard correlation integral technique between the water-path and through-tissue signals [23]. The source transducer was driven by a low-power Panametrics 5800 pulser/receiver (Panametrics, Inc., Waltham, MA). The pulser/receiver operated in both the pulse-echo mode and the through-transmission mode, and its $2-\mathrm{kHz}$ pulse repetition frequency signal was fed to the source transducer. The source transducer, the hydrophone, and the specially designed holder supporting the chest-wall sample were immersed in degassed water $\left(22 \pm 0.5^{\circ} \mathrm{C}\right)$. The ultrasonic source was a focused, 19-mm-diameter transducer (Panametrics, Inc., Waltham, MA) with the following measured [26] characteristics: center frequency of $7.0 \mathrm{MHz}$, fractional bandwidth of $40 \%$, focal length of $97 \mathrm{~mm},-6$ $\mathrm{dB}$ focal beamwidth of $1.1 \mathrm{~mm}$, and $-6-\mathrm{dB}$ depth of focus of $38 \mathrm{~mm}$. The hydrophone was a $1-\mathrm{mm}^{2}$ bilaminar membrane hydrophone (Perceptron Model 804, Plymouth Meeting, PA). The sample was positioned between the broadbanded source transducer and the hydrophone. The hydrophone was placed as close as possible to the sample with the source transducer's focus at the location of the hydrophone.

The chest-wall samples were acclimatized to the water's temperature $\left(22 \pm 0.5^{\circ} \mathrm{C}\right)$ for a period of at least 15 minutes prior to data acquisition. For the 5-day, 31-day, and 61-day pigs, respectively, data were acquired from 600 , 1000, and 1000 adjacent lateral positions in increments of $50 \mu \mathrm{m}$, that is, over $30-, 50-$, and $50-\mathrm{mm}$ lengths. Acquired data at the same sample locations consisted of the through-transmission RF signals from which attenuation and speed were estimated, and pulse-echo RF signals for a B-mode image from which the intercostal tissue thickness was estimated. The B-mode image and the normalized acoustic pressure profiles as a function of lateral scanned position (Fig. 2) were displayed simultaneously. These two displays were used to locate the intercostal tissue. The ribs were clearly seen in the B-mode image, and the normal- 
ized acoustic pressure profile demonstrated a substantial amplitude decrease through the region in which the ribs were located. Through-transmission reference data were acquired with degassed water between the source transducer and hydrophone. No bubbles were visible on the chest-wall samples; shaved and depilated chest walls were used. If bubbles had been present, it is hypothesized that they would have shown up on the B-mode image. However, no bubbles were visible by the naked eye or in the Bmode images of the chest-wall samples. Also, even though the attenuation losses included surface reflection losses, they were considered to be insignificant and were not measured separately. The digitized pulse-echo and throughtransmission RF signals were transferred to a Sun UltraSparc (Sun Microsystems, Inc., Santa Clara, CA) workstation and analyzed using Matlab ${ }^{\circledR}$ (The MathWorks, Inc., Natick, MA).

The reported values for both the attenuation coefficient and the propagation speed had slight errors. The analysis to estimate the errors was reported elsewhere [23]. The errors were based on the intercostal tissue thickness, determined from the B-mode image for which a propagation speed of $1540 \mathrm{~m} / \mathrm{s}$ was used. But, the tissue propagation speed was, in general, different from $1540 \mathrm{~m} / \mathrm{s}$. The errors were assessed against the intercostal tissue thickness measured with the digital micrometer (accuracy: $10 \mu \mathrm{m}$; Mitutoyo Corp., Kawasaki, Kanagawa, Japan). The attenuation coefficient errors ranged between -1.8 and $+7.4 \%$, and the propagation speed errors ranged between -0.02 and $+0.45 \%$. These errors were much less than the standard errors of propagation speed and attenuation coefficient. Therefore, no correction to the propagation speeds and attenuation coefficients as determined from the intercostal tissue thickness (from the B-mode image) was made.

\section{Microscopic Measurement of Layers of the Intercostal Tissue}

The compositional analysis was performed on the intercostal tissues of crossbred pigs that were not included in this attenuation coefficient/propagation speed study. Chest walls were obtained from pigs immediately following euthanasia under anesthesia. They were fixed by immersion in $10 \%$ neutral-buffered formalin, processed, decalcified, embedded in paraffin, sectioned at $5 \mu \mathrm{m}$, stained with hematoxylin and eosin, and evaluated with light microscopy. Chest walls were embedded in paraffin with an orientation such that histologic sections were cut at right angles to the ribs through four to five ribs. The tissue between the ribs (intercostal tissue: skin, panniculus muscle, subcutaneous adipose tissue [fat], and intercostal muscle) from the skin surface to the parietal pleura was used for measurements. A digital image of each intercostal tissue area was obtained using a Nikon Optiphot-2 (Nikon, Melville, NY) microscope equipped with a $1 \mathrm{X}$ objective and a Sony color video camera (Sony Electronics, Inc., San Jose, CA). In addition, a digital image of a slide micrometer $(2-\mathrm{mm}$ total length divided into units of $10 \mu \mathrm{m})$ was
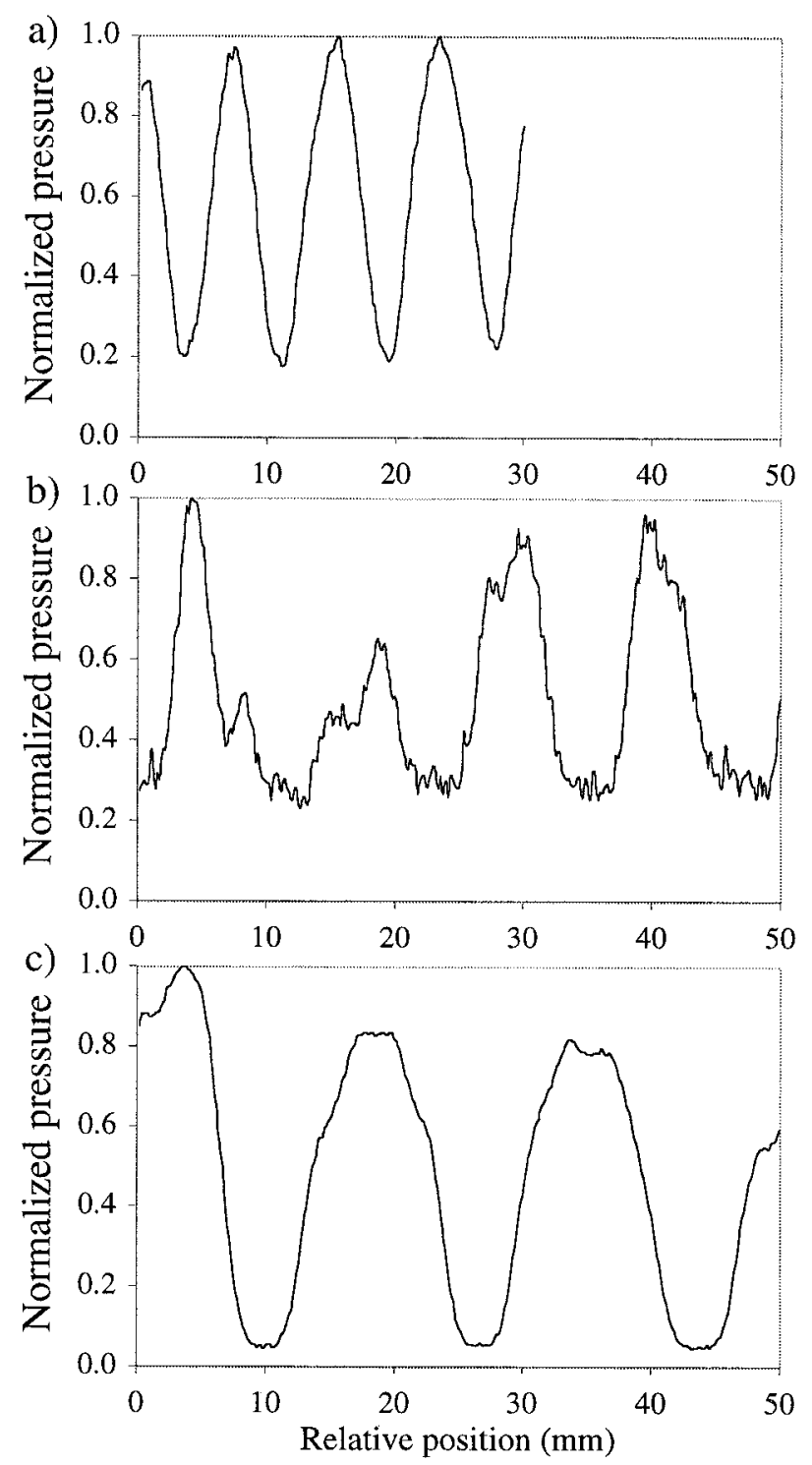

Fig. 2. Typical through-transmission (normalized) acoustic pressure profiles as a function of lateral scanned position for (a) 5-day pig, (b) 31-day-pig, and (c) 61-day-pig chest walls from which the intercostal (between the ribs) tissue location (maximum acoustic pressure values) is identified, and the attenuation coefficient of the intercostal tissue is estimated. The location of the ribs is at the minimum acoustic pressure values.

obtained with a $1 \mathrm{X}$ objective using the same microscopy system. Using Adobe Photoshop (San Jose, CA), the digital image of intercostal tissue for each pig chest wall was overlaid with the digital image of the slide micrometer. The width of each tissue layer in the intercostal space was determined in each animal using this procedure.

\section{E. Statistics}

The linear regression analysis [27] yielded the $\pm 95 \%$ confidence band for the regression line, the coefficient of determination, $r^{2}$, the standard error of regression (SER), and the standard error of the slope (SES). It is common to see the attenuation coefficient normalized to frequency (in 


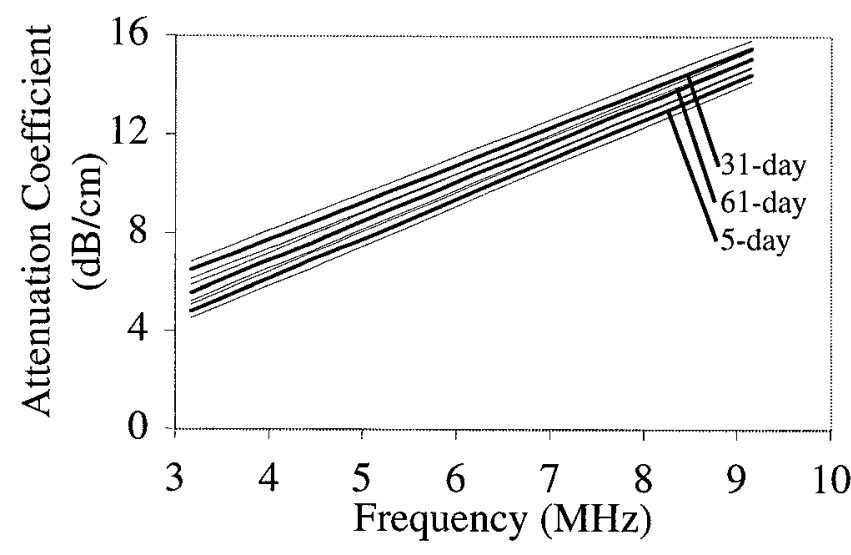

Fig. 3. Regression analyses (linear regression lines $\pm 95 \%$ confidence band for the regression line) of intercostal tissue attenuation coefficient as a function of frequency for the 15 5-day pigs, 19 31-day pigs, and 15 61-day pigs from Experiment 1.

$\mathrm{dB} / \mathrm{cm}-\mathrm{MHz}$ ) which is the slope term for these regressions, to which the SES applies.

To test for equality of the three regression lines for each animal, an analysis of covariance F-test [28] was performed. The null model constrains the intercepts and slopes to be equal across different pig ages. The general model allows for unequal intercepts and slopes for the pig ages. If not rejected, the null model was used. If it was rejected, the general model was used.

\section{RESULTS}

\section{A. Experiment 1}

The frequency range for the pig intercostal tissue attenuation coefficients was between 3.1 and $9.2 \mathrm{MHz}$ in 0.5 $\mathrm{MHz}$ increments (13 frequencies per tissue sample). For each chest wall, there were 13 frequencies and hence 13 attenuation coefficient values. Thus, for the 155 -day pig chest walls, there were 195 data points $(15 \times 13)$; for the 19 31 -day pig chest walls, there were 247 data points $(19 \times 13)$; and for the 15 61-day pig chest walls, there were 195 data points $(15 \times 13)$ that were used for the linear regression analyses.

Graphical representation of the frequency-dependent linear regression analyses is shown in Fig. 3 for the intercostal tissue from the chest walls of 155 -day pigs, 19 31day pigs, and 1561 -day pigs. The linear regression equations for the three curves are:

$$
\begin{gathered}
\mathrm{A}=1.50 \mathrm{f}+1.70 \quad 155 \text {-day pigs } \\
\text { frequency range: } 3.1-9.2 \mathrm{MHz} \\
\mathrm{n}=195, \mathrm{r}^{2}=0.55, \mathrm{SER}=2.6, \mathrm{SES}=0.098 \\
\mathrm{~A}=1.61 \mathrm{f}-0.30 \quad 1931 \text {-day pigs } \\
\text { frequency range: } 3.1-9.2 \mathrm{MHz} \\
\mathrm{n}=247, \mathrm{r}^{2}=0.64, \mathrm{SER}=2.3, \mathrm{SES}=0.077
\end{gathered}
$$

$$
\begin{gathered}
\mathrm{A}=1.59 \mathrm{f}+0.51 \quad 1561 \text {-day pigs } \\
\text { frequency range: } 3.1-9.2 \mathrm{MHz} \\
\mathrm{n}=195, \mathrm{r}^{2}=0.62, \mathrm{SER}=2.3, \mathrm{SES}=0.089,
\end{gathered}
$$

where the attenuation coefficient $(\mathrm{A})$ is in $\mathrm{dB} / \mathrm{cm}$ and the ultrasonic frequency (f) is in MHz.

Comparison of the crossbred pig attenuation coefficients in the general model [28] for the three pig ages indicates that the three linear regressions are significantly different $(\mathrm{p}<0.0001)$. However, combining all of the attenuation coefficient data from the 49 crossbred pig chest walls yielded:

$$
\begin{gathered}
\mathrm{A}=1.60 \mathrm{f}+0.56 \quad 49 \mathrm{pigs} \text { frequency range: } 3.1-9.2 \mathrm{MHz} \\
\mathrm{n}=637, \mathrm{r}^{2}=0.59, \mathrm{SER}=2.4, \mathrm{SES}=0.052
\end{gathered}
$$

A power law fit also was determined for the above three age-dependent data sets, and are over the $3.1-9.2 \mathrm{MHz}$ frequency range:

$$
\begin{array}{lll}
\mathrm{A}=2.39 \mathrm{f}^{0.83} & \mathrm{r}^{2}=0.55 & 15 \text { 5-day pigs } \\
\mathrm{A}=1.58 \mathrm{f}^{0.98} & \mathrm{r}^{2}=0.62 & 19 \text { 31-day pigs } \\
\mathrm{A}=2.04 \mathrm{f}^{0.88} & \mathrm{r}^{2}=0.64 & 15 \text { 61-day pigs }
\end{array}
$$

Combining all of the attenuation coefficient data from the 49 crossbred pig chest walls yielded:

$$
\mathrm{A}=1.94 \mathrm{f}^{0.90} \quad \mathrm{r}^{2}=0.59 \quad 49 \text { pigs }
$$

Comparisons of the intercostal tissue attenuation coefficient $(\mathrm{dB} / \mathrm{cm}-\mathrm{MHz})$ data for the three pig ages were performed at the discrete frequencies of 3.1, 6.2 and $9.2 \mathrm{MHz}$ for each age group (Fig. 4). Table I lists the attenuation coefficient at the discrete frequencies of 3.1, 4.6, 6.2, 7.6, and 9.2 MHz for each age group. A single-factor Analysis of Variance (ANOVA) indicates that, at each of the five frequencies, there is no statistically significant difference as a function of pig age. Because there was no age-dependent difference, the results were combined to yield overall mean $(\mathrm{SEM}, \mathrm{n}=49)$ attenuation coefficients $(\mathrm{dB} / \mathrm{cm}-\mathrm{MHz})$ of: $2.02(0.082)$ at $3.1 \mathrm{MHz}, 1.62(0.059)$ at $4.6 \mathrm{MHz}, 1.59$ $(0.054)$ at $6.2 \mathrm{MHz}, 1.65(0.052)$ at $7.6 \mathrm{MHz}$, and 1.66 (0.048) at $9.2 \mathrm{MHz}$. However, there were significant differences (single-factor ANOVA) of the same pig at the five frequencies, as the power-law dependencies on frequency reported above would lead us to expect.

Propagation speeds as a function of pig age are shown in Fig. 5. The mean (SEM) propagation speeds $(\mathrm{m} / \mathrm{s})$ are for the 5-day pigs 1493 (14), for the 31-day pigs 1568 (11), and for the 61-day pigs 1586 (12). A single-factor ANOVA showed that there was a statistically significant difference as a function of pig age $(\mathrm{p}<0.0001)$. Furthermore, there were significant differences (two-tail, two-sample t-test assuming unequal variances) between the 5-day pigs and 31day pigs $(\mathrm{p}$-value $=0.0002)$ and between the 5 -day pigs and 61 -day pigs ( $\mathrm{p}$-value $<0.0001$ ), whereas there was no significant difference between the 31-day pigs and 61-day pigs $(\mathrm{p}$-value $=0.29)$. 
TABLE I

Mean (Standard Error of the Mean) Attenuation Coefficient Values of Intercostal Tissue as a Function of Age and Ultrasonic Frequency from Crossbred Pigs.*

\begin{tabular}{lcccc}
\hline & \multicolumn{2}{c}{ Attenuation coefficient $(\mathrm{dB} / \mathrm{cm}=\mathrm{MHz})$} & Age-dependent \\
\cline { 2 - 4 } & 5-day pigs & 31-day pigs & 61-day pigs & p-value \\
\hline$@ 3.1 \mathrm{MHz}$ & $2.21(0.19)$ & $1.81(0.10)$ & $2.09(0.12)$ & 0.11 \\
$@ 4.6 \mathrm{MHz}$ & $1.83(0.13)$ & $1.47(0.079)$ & $1.61(0.092)$ & 0.061 \\
$@ 6.2 \mathrm{MHz}$ & $1.73(0.11)$ & $1.48(0.081)$ & $1.59(0.092)$ & 0.16 \\
$@ 7.6 \mathrm{MHz}$ & $1.72(0.09)$ & $1.58(0.083)$ & $1.66(0.096)$ & 0.57 \\
$@ 9.2 \mathrm{MHz}$ & $1.73(0.092)$ & $1.60(0.076)$ & $1.68(0.086)$ & 0.49 \\
Frequency-dependent p-value & 0.038 & 0.048 & 0.003 & \\
\hline
\end{tabular}

*The age-dependent p-values listed are for the age-dependent rows and the frequency-dependent p-values listed are for the frequency-dependent columns where $\mathrm{n}=15$ for the 5-day pigs, $\mathrm{n}=19$ for the 31-day pigs, and $\mathrm{n}=15$ for the 61 -day pigs.

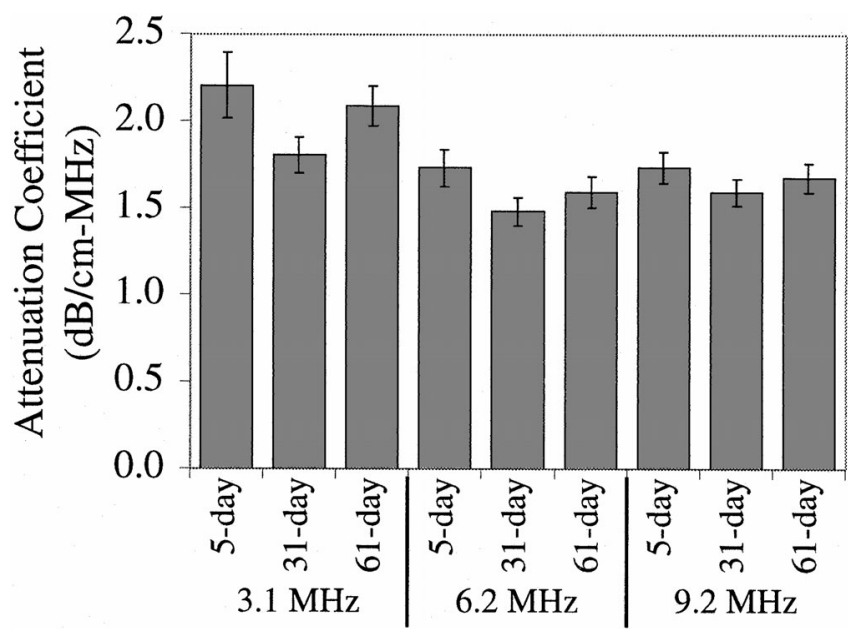

Fig. 4. Intercostal tissue mean attenuation coefficients as a function of pig age at three frequencies $(3.1,6.2$, and $9.2 \mathrm{MHz})$ for the 15 5-day pigs, 19 31-day pigs, and 15 61-day pigs from Experiment 1. Error bars are SEMs.

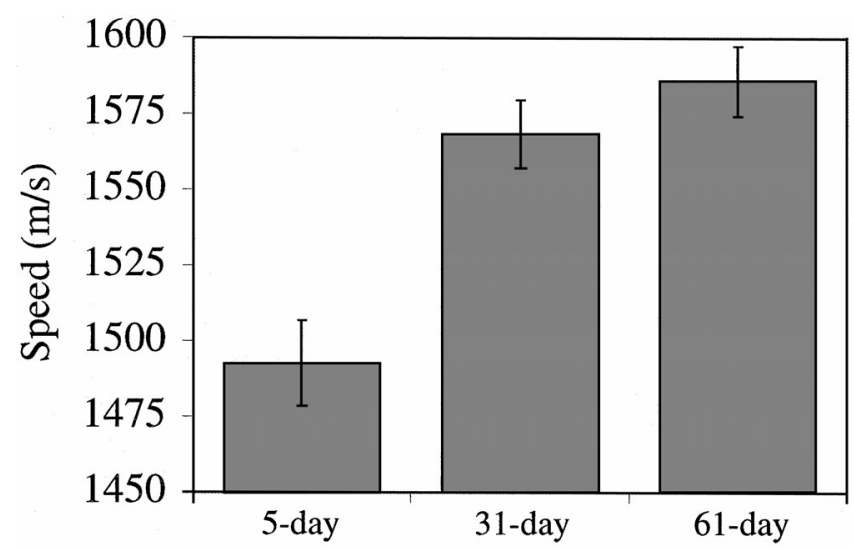

Fig. 5. Intercostal tissue mean propagation speed as a function of pig age for the 15 5-day pigs, 19 31-day pigs, and 15 61-day pigs from Experiment 1. Error bars are SEMs.

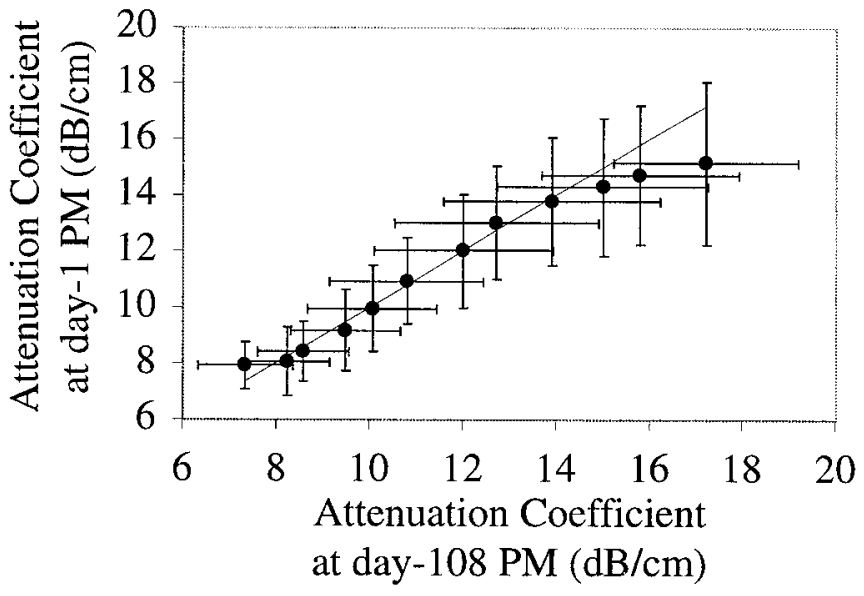

Fig. 6. Intercostal tissue mean attenuation coefficients at day-1 pm versus the intercostal tissue mean attenuation coefficients at day-108 pm for the same five 5-day-pig chest-wall samples for Experiment 2. Each data point represents one of the 13 frequencies; frequency increases from lower left $(3.1 \mathrm{MHz})$ to upper right $(9.2 \mathrm{MHz})$. The straight line has a slope of unity. Error bars are SEMs.

\section{B. Experiment 2}

The same five pig chest-wall samples were evaluated at two time points (day 1 and day $108 \mathrm{pm}$ ) to determine if there was an effect of the length of storage time on the intercostal tissue attenuation coefficient and propagation speed. These five chest-wall samples were from Experiment 1. The attenuation coefficient was essentially unchanged between the two time points (Fig. 6) whereas there was a significant difference in the propagation speed between the two time points pm (Fig. 7).

\section{Compositional Analysis}

The compositional analysis was performed for the intercostal tissues of 41 crossbred pigs. None of these chest walls were included in this attenuation coefficient/propagation speed study because it had not been determined that compositional analysis might be important until the lung hemorrhage data [22] and chest-wall properties had been initially evaluated. The ranges of the pig ages were: 4 to 5 


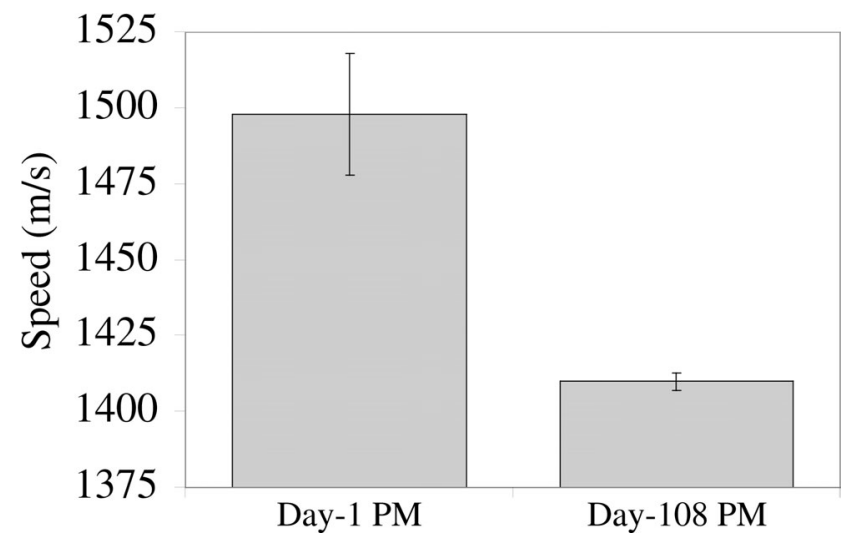

Fig. 7. Intercostal tissue mean propagation speed at day- $1 \mathrm{pm}$ and at day-108 pm for the same five 5-day-pig chest-wall samples for Experiment 2. Error bars are SEMs.

days $(4.5 \pm 0.2-\mathrm{mm}$ intercostal tissue thickness, $3.4 \pm 0.1-\mathrm{kg}$ weight, $\mathrm{n}=15) ; 27$ to 30 days $(12.2 \pm 0.5$-mm intercostal tissue thickness, $8.8 \pm 0.2-\mathrm{kg}$ weight, $\mathrm{n}=13$ ); and 58 to 62 days $(17.4 \pm 0.5$-mm intercostal tissue thickness, $20 \pm 0.7-\mathrm{kg}$ weight, $\mathrm{n}=13$ ). These ages approximately matched the ages from Experiment 1. The percentages of skin, fat and muscle are shown in Fig. 8(a) for all 41 intercostal tissues, grouped by pig age and ordered in each age group by increased age. Fig. 8(b) shows the mean percentages of skin, fat, and muscle for each age group, and includes similar data for 6- to 7-week-old ICR mice and 10- to 11-weekold Sprague-Dawley (SD) rats (both species from Harlan Laboratories, Indianapolis, IN).

\section{Discussion}

The purpose of determining the acoustic propagation properties of intercostal tissue is to provide a quantitative basis for estimating acoustic pressure at the lung surface after ultrasound has been transmitted through the intercostal tissue. There were two important findings. The attenuation coefficient of intercostal tissue at discrete frequencies is independent of the pig age, and the attenuation coefficient of intercostal tissue is not affected substantially by sample storage time pm.

There are no known studies that have examined the attenuation coefficient of intercostal tissue as a function of the animal's age. There are, however, two separate reports that document the chest-wall attenuation coefficient of 1day-old [20] and 10-day-old [21] crossbred pigs. In both reports, by the same research group, approximately the same attenuation coefficient is reported for both ages at a frequency of $2.3 \mathrm{MHz}$. For the 1-day-old pig intercostal tissues, the attenuation coefficient is reported to be 3.0 $3.4 \mathrm{~dB} / \mathrm{cm}$ (or 1.3-1.5 dB/cm-MHz; two samples), and for the 10-day-old pig intercostal tissues, the attenuation coefficient is reported to be $2.9 \mathrm{~dB} / \mathrm{cm}$ (or $1.2 \mathrm{~dB} / \mathrm{cm}-\mathrm{MHz}$; nine samples). These intercostal tissue attenuation coefficient values are about the same as those reported for adult ICR mice and SD rats of $1.1 \mathrm{~dB} / \mathrm{cm}-\mathrm{MHz}(2-8 \mathrm{MHz})$ [24]. a)

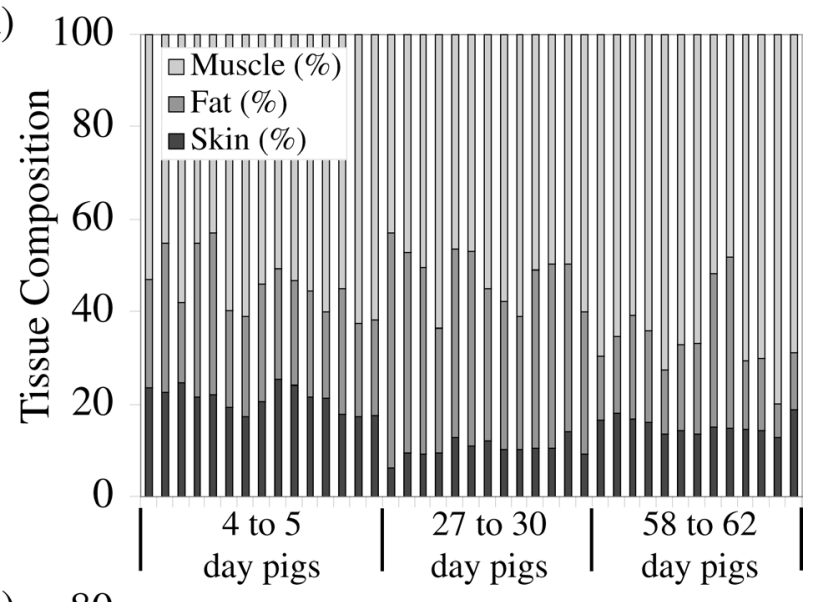

b)

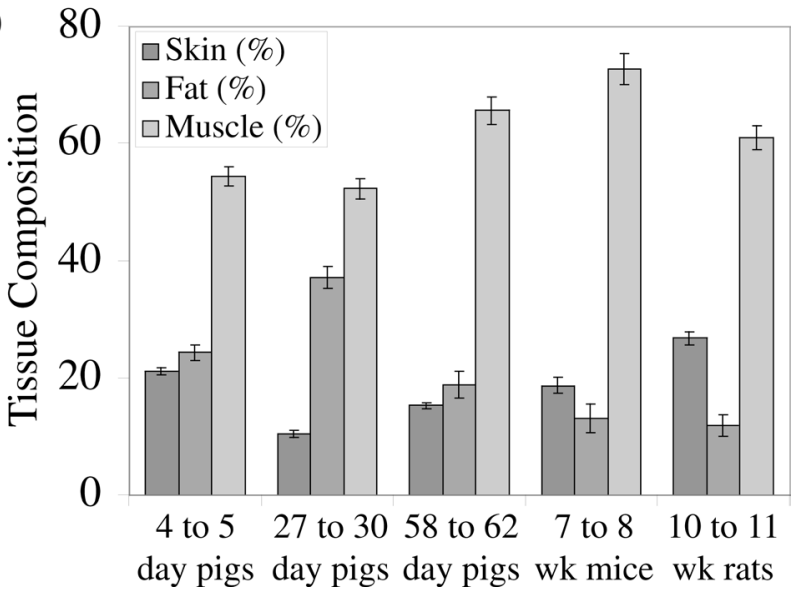

Fig. 8. (a) Intercostal tissue compositional analyses (skin, fat, and muscle) for each of 41 samples as a function of pig age. Within each age bracket, the compositional analyses are arranged by increasing age. (b) Mean percentages of skin, fat, and muscle of the intercostal tissue from 15 4- to 5-day-old crossbred pigs, 1327 - to 30-day-old crossbred pigs, 13 58- to 62-day-old crossbred pigs, 6- to 7-week-old ICR mice, and 10- to 11-week-old Sprague-Dawley rats. Error bars are SEMs.

Furthermore, they are about half those reported herein for crossbred pig intercostal tissue of $2.21 \mathrm{~dB} / \mathrm{cm}-\mathrm{MHz}$ (at $3.1 \mathrm{MHz}$ ) for the 5-day crossbred pigs. Our comparisons are with the discrete-frequency attenuation coefficient because the other group's results are likewise at discrete frequencies. We have no explanation as to why our intercostal tissue attenuation coefficients reported herein for the three ages of pigs are different from those reported by another research group [20], [21].

In order to understand why pig intercostal tissue attenuation coefficients were different from mice and rats (using the same measurement and analysis procedures), the tissue constituents were determined. Intercostal tissue is composed of different tissue types (skin, adipose tissue [fat], intercostal muscle). Previously [24], we reported the following percentages (mean) of intercostal tissue constituents for ICR mice and SD rats, respectively: $19 \%$ and $27 \%$ for skin, $13 \%$ and $12 \%$ for fat, and $68 \%$ and $61 \%$ for muscle. Herein we report the following percentages (mean) of intercostal tissue constituents for 5-day, 31-day, and 61-day crossbred pigs, respectively: $21 \%, 10 \%$, and 
$15 \%$ for skin; $24 \%, 37 \%$, and $19 \%$ for fat; and $54 \%, 52 \%$, and $66 \%$ for muscle. In general, the percentages of skin, fat, and muscle were similar for the three species (Fig. 8) with an interesting exception. Fat concentration is greater than skin concentration in pigs; fat concentration is less than skin concentration in rodents. There was some variation in the percentages of intercostal tissue constituents for the three pig ages, even though their attenuation coefficients were the same. Furthermore, the mouse and rat tissue constituent variation fell within the ranges of the pig constituent variation, even though their intercostal tissue attenuation coefficients were quite different from those of the pigs. Thus, the constituent variation seemed to have little, if any, effect on the attenuation coefficient. It might be speculated that the attenuation coefficient differences of intercostal tissue between pig and the two rodent species are due to the distribution of tissue constituents, not the concentration of each constituent.

The intercostal tissue propagation speed from 5-day pigs is considerably less than that from 31-day and 61day pigs (Fig. 5). Skin is thought of as having a higher propagation speed than muscle [29]-[33]; fat is thought of as having a lower propagation speed than muscle [29]-[31], [34]. The variation of tissue constituents does not explain the measured differences (Fig. 8).

Sample storage time pm did not appear to substantially affect the intercostal tissue attenuation coefficient in crossbred pigs. There was an interesting finding that, at the highest frequencies measured, the attenuation coefficient at 108-day pm was greater than that at 1-day pm; it can be speculated only that the 108-day pm changes in tissue are more sensitive at the higher frequencies than at the lower frequencies. Otherwise, the finding that sample storage time pm did not affect the attenuation coefficient is consistent with our previous finding that sample storage time pm did not affect the intercostal tissue attenuation coefficient in adult mice and rats [24].

\section{ACKNOWLEDGMents}

We thank Professor D. Simpson for statistical analysis advice, Dr. C. Frazier for assistance in developing the analysis programs, and D. Abano, R. Bashyal, J. Blue, J. Brown, J. Christoff, B. McNeill, K. Norrell, R. Patel, P. Paul, S. Sakai, and A. Tevar for their technical contributions.

\section{REFERENCES}

[1] S. Z. Child, C. L. Hartman, L. A. Schery, and E. L. Carstensen, "Lung damage from exposure to pulsed ultrasound," Ultrasound Med. Biol., vol. 16, pp. 817-825, 1990.

[2] C. Hartman, S. Z. Child, R. Mayer, E. Schenk, and E. L. Carstensen, "Lung damage from exposure to the fields of an electrohydraulic lithotripter," Ultrasound Med. Biol., vol. 16, pp. 675-679, 1990
[3] D. P. Penney, E. A. Schenk, K. Maltby, C. Hartman-Raeman, S. Z. Child, and E. L. Carstensen, "Morphologic effects of pulsed ultrasound in the lung," Ultrasound Med. Biol., vol. 19, pp. 127135, 1993.

[4] C. H. Raeman, S. Z. Child, and E. L. Carstensen, "Timing of exposures in ultrasonic hemorrhage of murine lung," Ultrasound Med. Biol., vol. 19, pp. 507-517, 1993.

[5] L. A. Frizzell, E. Chen, and C. Lee, "Effects of pulsed ultrasound on the mouse neonate: Hind limb paralysis and lung hemorrhage," Ultrasound Med. Biol., vol. 20, pp. 53-63, 1994.

[6] J. F. Zachary and W. D. O'Brien, Jr., "Lung lesion induced by continuous- and pulsed-wave (diagnostic) ultrasound in mice, rabbits, and pigs," Vet. Pathol., vol. 32, pp. 43-54, 1995.

[7] C. H. Raeman, S. Z. Child, D. Dalecki, C. Cox, and E. L. Carstensen, "Exposure-time dependence of the threshold for ultrasonically induced murine lung hemorrhage," Ultrasound Med. Biol., vol. 22, pp. 139-141, 1996.

[8] W. D. O'Brien, Jr. and J. F. Zachary, "Lung damage assessment from exposure to pulsed-wave ultrasound in the rabbit, mouse, and pig," IEEE Trans. Ultrason., Ferroelect., Freq. Contr., vol. 44, pp. 473-485, 1997.

[9] D. Dalecki, S. Z. Child, C. H. Raeman, C. Cox, D. P. Penney, and E. L. Carstensen, "Age dependence of ultrasonically induced lung hemorrhage in mice," Ultrasound Med. Biol., vol. 23, pp. 767-776, 1997.

[10] W. D. O'Brien, Jr., L. A. Frizzell, R. M. Weigel, and J. F. Zachary, "Ultrasound-induced lung hemorrhage is not caused by inertial cavitation," J. Acoust. Soc. Amer., vol. 108, pp. 1290$1297,2000$.

[11] W. D. O'Brien, Jr., L. A. Frizzell, D. J. Schaeffer, and J. F. Zachary, "Superthreshold behavior of ultrasound-induced lung hemorrhage in adult mice and rats: Role of pulse repetition frequency and pulse duration," Ultrasound Med. Biol., vol. 27, pp. 267-277, 2001.

[12] J. F. Zachary, J. M. Sempsrott, L. A. Frizzell, D. G. Simpson, and W. D. O'Brien, Jr., "Superthreshold behavior and threshold estimation of ultrasound-induced lung hemorrhage in adult mice and rats," IEEE Trans. Ultrason., Ferroelect., Freq. Contr., vol. 48, pp. 581-592, 2001.

[13] C. K. Holland, K. Sandstrom, X. Zheng, J. Rodriguey, and R. A. Roy, "The acoustic field of a pulsed Doppler diagnostic ultrasound system near a pressure-release surface, (abstract)," $J$. Acoust. Soc. Amer., vol. 95, p. 2855, 1994.

[14] C. K. Holland, C. X. Deng, R. E. Apfel, J. L. Alderman, L. A. Fernandez, and K. J. W. Taylor, "Direct evidence of cavitation in vivo from diagnostic ultrasound," Ultrasound Med. Biol., vol. 22, pp. 917-925, 1996.

[15] J. F. Zachary, L. A. Frizzell, K. S. Norrell, J. P. Blue, R. J. Miller, and W. D. O'Brien, Jr., "Temporal and spatial evaluation of lesion resolution following exposure of rat lung to pulsed ultrasound," Ultrasound Med. Biol., vol. 27, pp. 829-839, 2001.

[16] W. D. O'Brien, Jr., D. G. Simpson, L. A. Frizzell, and J. F. Zachary, "Superthreshold behavior and threshold estimates of ultrasound induced lung hemorrhage in adult rats: Role of beamwidth," IEEE Trans. Ultrason., Ferroelect., Freq. Contr., vol. 48 , pp. $1695-1705,2001$.

[17] J. M. Kramer, T. G. Waldrop, L. A. Frizzell, J. F. Zachary, and W. D. O'Brien, Jr., "Cardiopulmonary function in rats with lung hemorrhage induced by exposure to superthreshold pulsed ultrasound," J. Med. Ultrasound, vol. 20, pp. 1197-1206, 2001.

[18] W. D. O'Brien, Jr., J. M. Kramer, T. G. Waldrop, L. A. Frizzell, R. J. Miller, J. P. Blue, and J. F. Zachary, "Ultrasound-induced lung hemorrhage: Role of acoustic boundary conditions at the pleural surface," J. Acoust. Soc. Amer., vol. 111, pp. 1102-1109, 2002.

[19] A. F. Tarantal and D. R. Canfield, "Ultrasound-induced lung hemorrhage in the monkey," Ultrasound Med. Biol., vol. 20, pp. 65-72, 1994.

[20] R. Baggs, D. P. Penney, C. Cox, S. Z. Child, C. H. Raeman, D. Dalecki, and E. L. Carstensen, "Thresholds for ultrasonically induced lung hemorrhage in neonatal swine," Ultrasound Med. Biol., vol. 22, pp. 119-128, 1996.

[21] D. Dalecki, S. Z. Child, C. H. Raeman, C. Cox, and E. L. Carstensen, "Ultrasonically induced lung hemorrhage in young swine," Ultrasound Med. Biol., vol. 23, pp. 777-781, 1997.

[22] W. D. O'Brien, Jr., D. G. Simpson, M.-H. Ho, R. J. Miller, L. A. Frizzell, and J. F. Zachary, "Superthreshold behavior and 
threshold estimation of ultrasound-induced lung hemorrhage in pigs: Role of age dependency," submitted for publication.

[23] R. T. Towa, R. J. Miller, L. A. Frizzell, J. F. Zachary, and W. D. O'Brien, Jr., "Attenuation coefficient and propagation speed estimates of rat and pig intercostal tissue as a function of temperature," IEEE Trans. Ultrason., Ferroelect., Freq. Contr., vol. 49, no. 10, pp. 1411-1420, 2002.

[24] G. A. Teotico, R. J. Miller, L. A. Frizzell, J. F. Zachary, and W. D. O'Brien, Jr., "Attenuation coefficient estimates of mouse and rat chest wall," IEEE Trans. Ultrason., Ferroelect., Freq. Contr., vol. 48, pp. 593-601, 2001.

[25] E. L Madsen, F. Dong, G. R. Frank, B. S. Gara, K. A. Wear, T. Wilson, J. A. Zagzebski, H. L. Miller, K. K. Shung, S. H. Wang, E. J. Feleppa, T. Liu, W. D. O'Brien, Jr., K. A. Topp, N. T. Sanghvi, A. V. Zaitsen, T. J. Hall, J. B. Fowlkes, O. D. Kripfgans, and J. G. Miller, "Interlaboratory comparison of ultrasonic backscatter, attenuation and speed measurements," $J$. Med. Ultrasound, vol. 18, pp. 615-631, 1999.

[26] K. Raum and W. D. O'Brien, Jr., "Pulse-echo field distribution measurement technique of high-frequency ultrasound sources," IEEE Trans. Ultrason., Ferroelect., Freq. Contr., vol. 44, pp. 810-815, 1997.

[27] J. Neter, M. H. Kutner, C. J. Nachtsheim, and W. Wasserman, Applied Linear Statistical Models. 4th ed. Chicago: Irwin, 1996, pp. 3-94.

[28] J. Neter, M. H. Kutner, C. J. Nachtsheim, and W. Wasserman, Applied Linear Statistical Models. 4 ed. Chicago: Irwin, 1996, pp. 1019-1027.

[29] F. A. Duck, Physical Properties of Tissue. A Comprehensive Reference Book. New York: Academic, 1990.

[30] S. A. Goss, R. L. Johnston, and F. Dunn, "Comprehensive compilation of empirical ultrasonic properties of mammalian tissues," J. Acoust. Soc. Amer., vol. 64, pp. 423-457, 1978.

[31] S. A. Goss, R. L. Johnston, and F. Dunn, "Compilation of empirical ultrasonic properties of mammalian tissues-II," J. Acoust. Soc. Amer., vol. 68, pp. 93-108, 1980.

[32] J. E. Olerud, W. D. O'Brien, Jr., M. A. Riederer-Henderson, D. Steiger, F. K. Forster, C. Daly, D. J. Ketterer, and G. F. Odland, "Ultrasonic assessment of skin and wounds with the scanning laser acoustic microscope," J. Investig. Dermatol., vol. 88, pp. 615-623, 1987.

[33] M. A. Riederer-Henderson, J. E. Olerud, W. D. O'Brien, Jr., F. K. Forster, D. L. Steiger, D. J. Ketterer, and G. F. Odland, "Biochemical and acoustical parameters of normal canine skin," IEEE Trans. Biomed. Eng., vol. 35, pp. 967-972, 1988.

[34] W. D. O'Brien, Jr., J. E. Erdman, Jr., and T. B. Hebner, "Ultrasonic propagation properties (@100 MHz) in excessively fatty rat liver," J. Acoust. Soc. Amer., vol. 83, pp. 1159-1166, 1988.

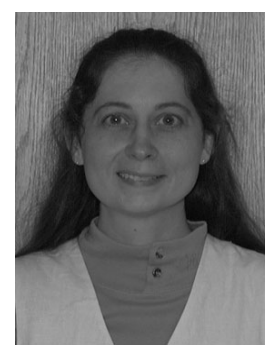

Rita J. Miller was born in San Diego, California. She received her D.V.M. at the University of Wisconsin, Madison in 1992.

Dr. Miller completed a small animal medical/surgical internship at the University of Illinois at Urbana-Champaign in 1993. She then worked as a Veterinary Poison Information Specialist at the National Animal Poison Control Center, also at the University of Illinois at Urbana-Champaign. While at the University of Illinois she has been involved with a variety of research projects. Evaluation of the efficacy of a new treatment for Erlichiosis in dogs. Rehabilitation with electrical muscle stimulation for dogs with surgically treated cranial cruciate ligament deficient stifles. Role of IGF-1 (insulin-like growth factor 1) and the IGF-1R (type one insulin-like growth factor one receptor) in the uterotrophic effect induced by the administration of tamoxifen. Identification and cloning of canine MMP-2 (matrix metalloproteinase-2). RT-PCR (reverse-transcription polymerase chain reaction) profiling of canine spontaneous tumors for the presence of MMP-2. Her current research involves the assessment of ultrasound-induced lung damage and attenuation coefficient determination of intercostal tissues.

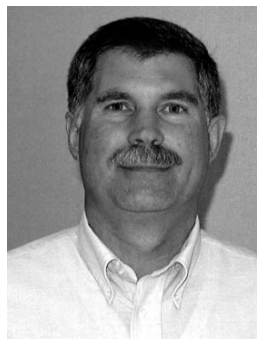

Leon A. Frizzell (S'71-M'74-SM'82) was born in West Stewartstown, NH, on September 12,1947 . He received the B.S. degree in physics from the University of New Hampshire, Durham, NH, in 1969, and the M.S. and Ph.D. degrees in electrical engineering from the University of Rochester, Rochester, NY, in 1971 and 1976, respectively.

Since 1975, he has been in the Department of Electrical and Computer Engineering at the University of Illinois at Urbana-Champaign, where he is currently Professor of Electrical and Computer Engineering and of Bioengineering. He was Acting Director of the Bioacoustics Research Laboratory within the Department of Electrical and Computer Engineering from August, 1989 to August, 1990 and served as Chair of the Bioengineering Faculty from August, 1995 to December, 1999. He was also a Visiting Research Scientist at Yale University from Aug, 1985 to August, 1986. His research interests are in ultrasound and include tissue characterization, biological effects, hyperthermia, surgery and bioengineering.

Dr. Frizzell is a Fellow of the American Institute of Ultrasound in Medicine, Fellow of the Acoustical Society of America, Fellow of the American Institute for Medical and Biological Engineering, and is a member of Eta Kappa Nu and Sigma Xi.

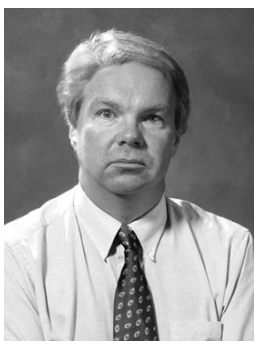

James F. Zachary received the B.S. degree from Northern Illinois University, Dekalb in 1972 and D.V.M. and Ph.D. degrees in 1977 and 1983, respectively, from the University from Illinois, Urbana-Champaign. From 1978, he has been at the University of Illinois, where he is a Professor of Pathology and a Bioengineering Faculty Member. His research interests involve ultrasound-tissue interactions and include biological effects, tissue characterization, blood-flow measurements, acoustic microscopy, and microbubble contrast agents. He has published more than 75 papers. Dr. Zachary has served as Editor-in-Chief of Veterinary Pathology and is currently a coeditor of the textbook Thomson's Special Veterinary Pathology. He is a Diplomate of the American College of Veterinary Pathologists and a member of the American Institute of Ultrasound in Medicine (AIUM), the American Society for Investigative Pathology (ASIPFASEB), and the Society for Neuroscience. He currently serves as vice-chair of the AIUM Bioeffects Committee.

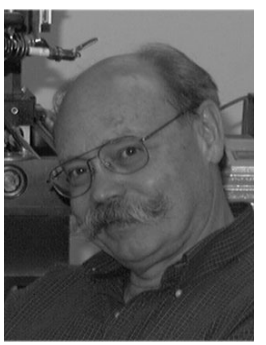

William D. O'Brien, Jr. (S'64-M'70SM'79-F'89) received the B.S., M.S., and Ph.D. degrees in 1966, 1968, and 1970, from the University of Illinois, Urbana-Champaign.

From 1971 to 1975 he worked with the Bureau of Radiological Health (currently the Center for Devices and Radiological Health) of the U.S. Food and Drug Administration. Since 1975, he has been at the University of Illinois, where he is a Professor of Electrical and Computer Engineering and of Bioengineering, College of Engineering; Professor of Bioengineering, College of Medicine; Professor of Nutritional Sciences, College of Agricultural, Consumer and Environmental Sciences; a Research Professor in the Beckman Institute for Advanced Science and Technology; and a Research Professor in the Coordinated Science Laboratory. He is the Director of the Bioacoustics Research Laboratory. His research interests involve the many areas of ultrasound-tissue interaction, including spectroscopy, risk assessment, biological effects, tissue characterization, dosimetry, blood-flow measurements, acoustic microscopy and imaging for which he has published 240 papers.

Dr. O'Brien is a Fellow of the Institute of Electrical and Electronics Engineers, the Acoustical Society of America and the American Institute of Ultrasound in Medicine, and a Founding Fellow of the 
American Institute of Medical and Biological Engineering. He was recipient of the IEEE Centennial Medal (1984), the AIUM Presidential Recognition Awards (1985 and 1992), the AIUM/WFUMB Pioneer Award (1988), the IEEE Outstanding Student Branch Counselor Award for Region 4 (1989), the AIUM Joseph H. Holmes Basic Science Pioneer Award (1993), and the IEEE Ultrasonics, Ferroelectrics, and Frequency Control Society Distinguished Lecturer (1997-1998). He received the IEEE Ultrasonics, Ferroelectrics, and Frequency Control Society's Achievement Award for 1998, and the IEEE Millennium Medal in 2000. He has served as Co-Chair of the 1981 and 2001 IEEE Ultrasonic Symposia, and General Chair of the 1988 IEEE Ultrasonics Symposium. He is Co-Chair of the 2003 IEEE Ultrasonics Symposium. He has been Secretary-Treasurer (19721980), Vice President (1981), and President (1982-1983) of the IEEE Sonics and Ultrasonics Group (currently the IEEE Ultrasonics, Ferroelectrics, and Frequency Control Society), and Editor-in-Chief of the IEEE Transactions on Ultrasonics, Ferroelectrics, and Frequency Control (1984-2001). He has been Treasurer (1982-1985), PresidentElect (1986-1988) and President (1988-1991) of the American Institute of Ultrasound in Medicine. He has served on the Board of Directors (1988-1993) of the American Registry of Diagnostic Medical Sonographers, and has been Treasurer (1991-1994) of the World Federation for Ultrasound in Medicine and Biology. 